ارزيابى جند عصارهگير جهت تعيين روى قابل استفاده گندم (Triticum aestivum L.) در خاكهاى آهكى تيمارشده و تيمارنشده با لجن فاضلاب

حميدرضا متقيان، "عليرضا حسين يور، جهانگرد محمدى و فايز رئيسى'

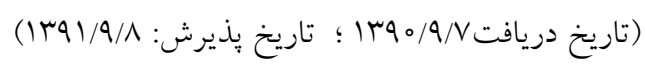

جكيده

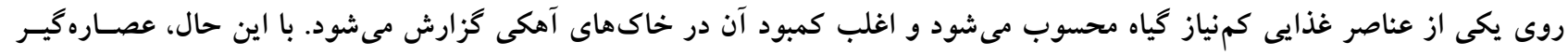

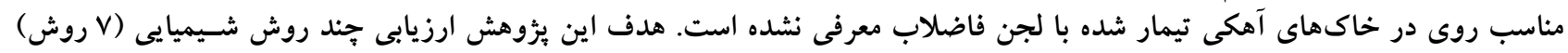

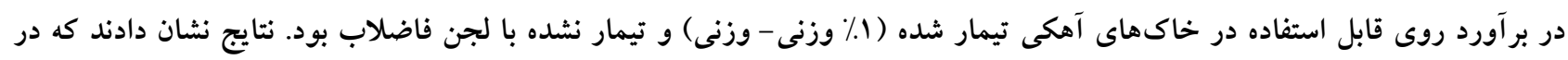

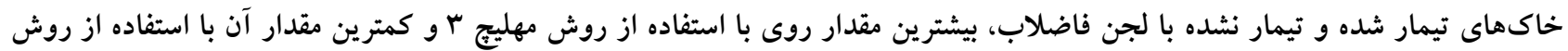

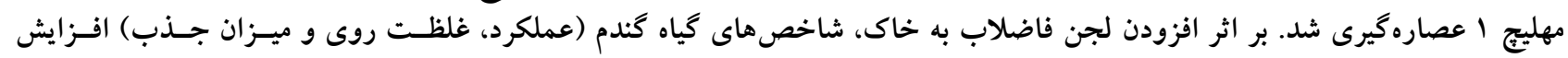

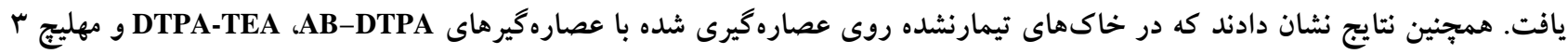

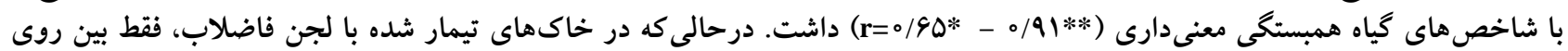

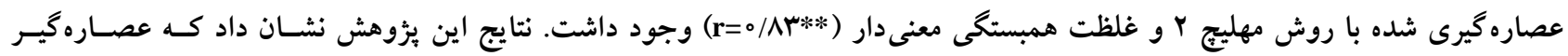

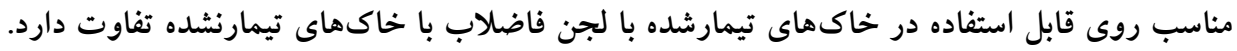

اصطلاحات كليدى: لجن فاضلاب، عصارهير هاى روى، كندم 
سـبب بهبـود خصوصسيات فيزيكسى خـاك از جملـه ظرفيـتـ

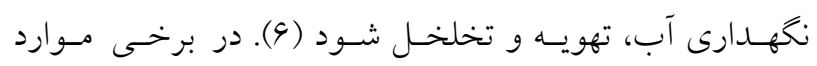

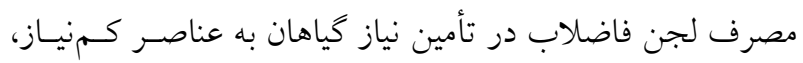

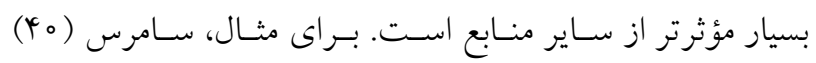

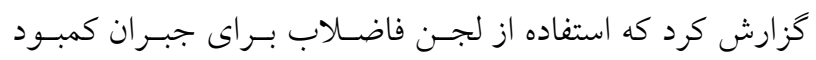

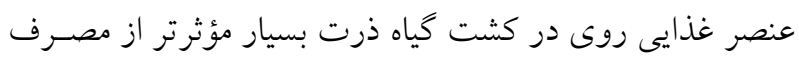

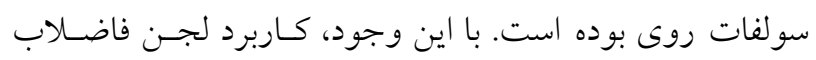
ممكن است سبب افزايش ميزان عناصر به حد سـميت در كيـاه آزمــون خـاك اطلاعـات مفيــى دربــاره مقــدار روى قابـل

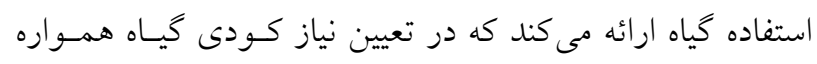

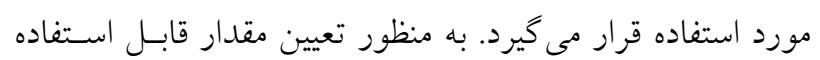

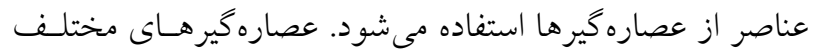

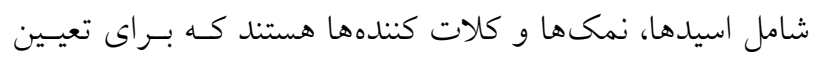
مقدار قابل استفاده عنصر روى در خاكهـا مـورد اسـتفاده قـرار

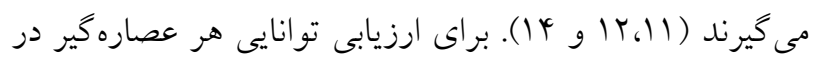

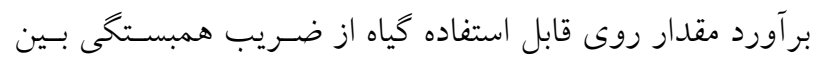

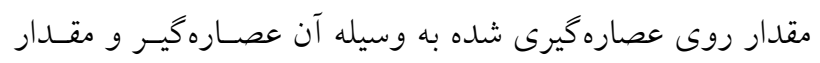

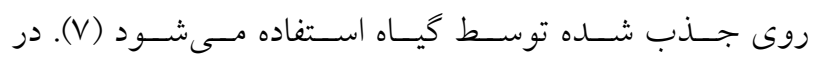

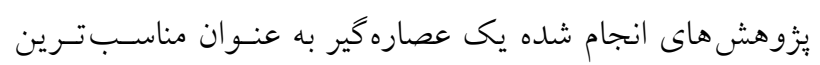

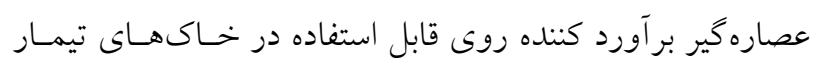

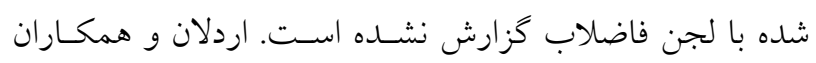

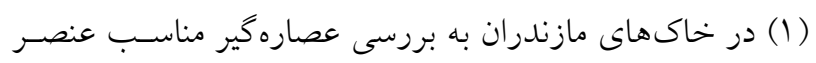

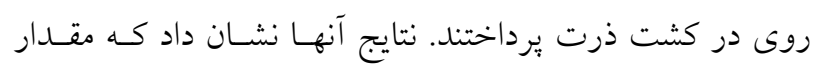

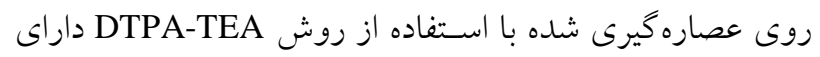

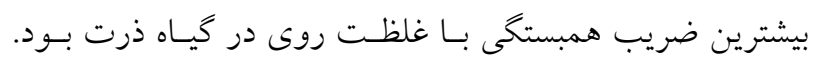

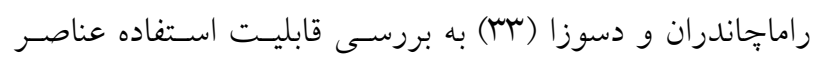

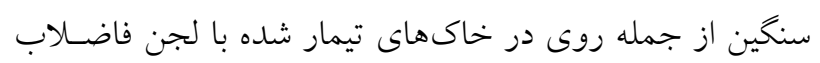

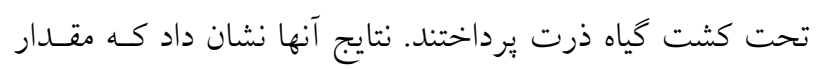

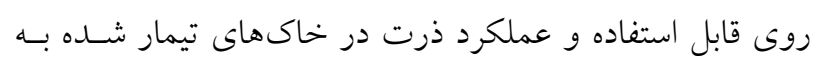

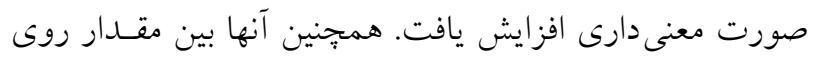

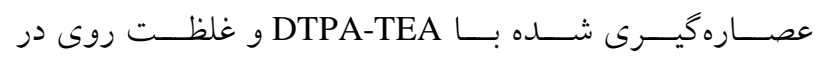

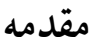

روى يكى از عناصر غذايى ضرورى براى رشد طبيعى و توليـــ

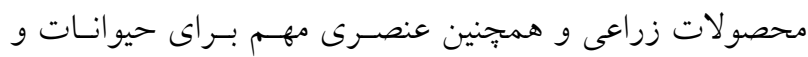

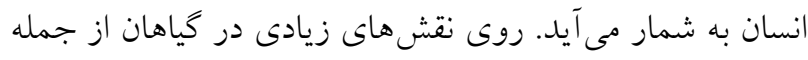

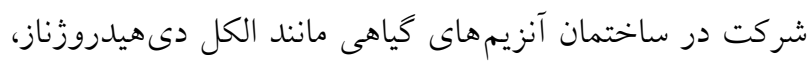

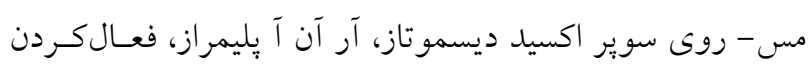

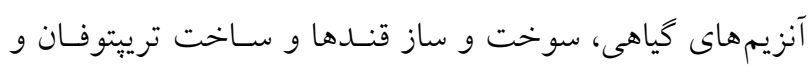

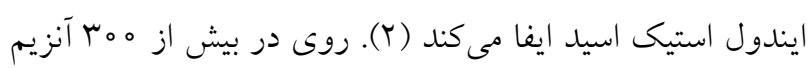

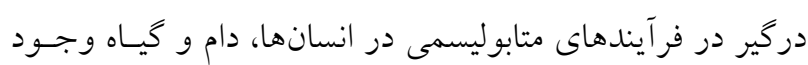

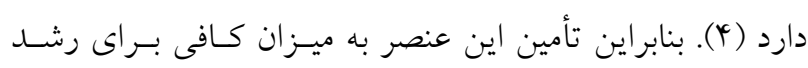
طبيعى انسانها نيز ضرورى است.

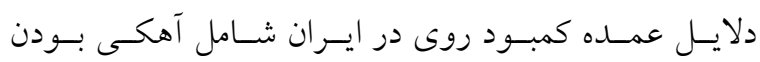

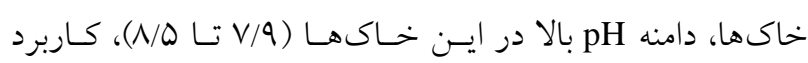

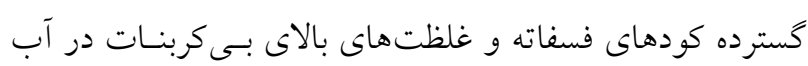

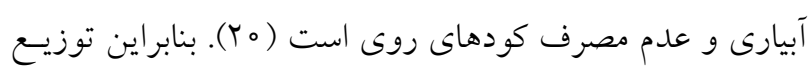

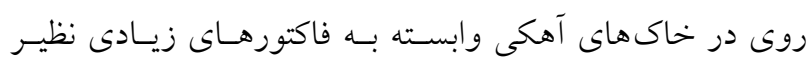

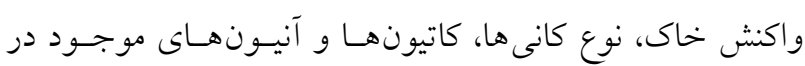

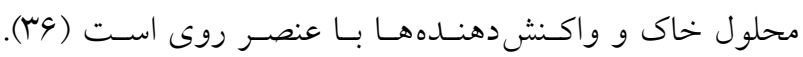
وقتى كه تأمين عنصر روى مورد نيـاز كيـاه كـافى نباشــان ميـزان

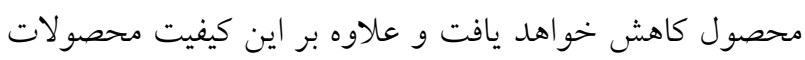
توليدشده نيز كاهش مىيابد (V).

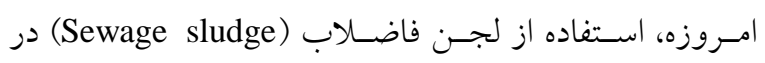

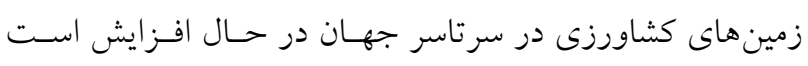

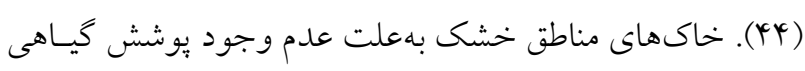

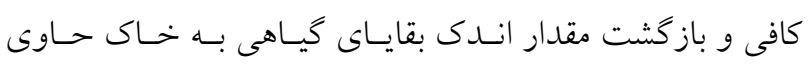

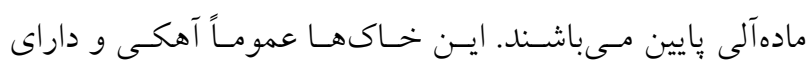

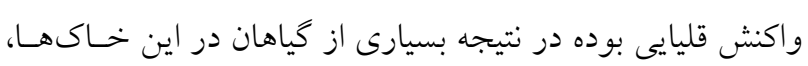

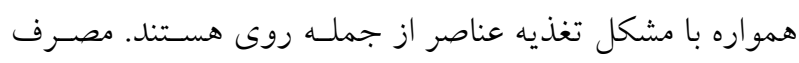

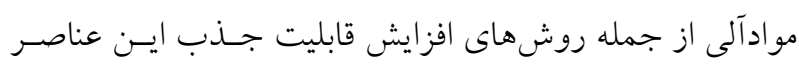

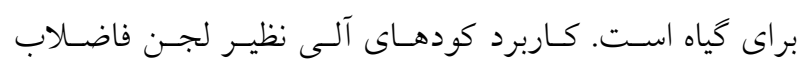

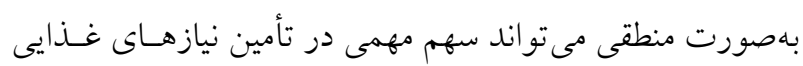

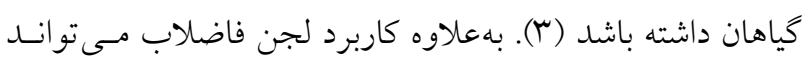


جدول ا. روشهاى عصاره گيرى شيميايى مورد استفاده در تعيين روى قابل استفاده

\begin{tabular}{|c|c|c|c|c|}
\hline منبع & زمان شيك & نسبت خاك- & تركيب عصاره كير & عصارهگير \\
\hline $1 \wedge$ & Iro & $1: r$ & 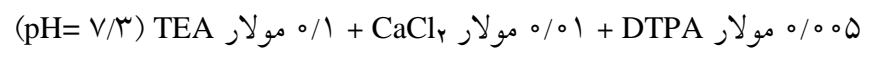 & DTPA-TEA \\
\hline rq & 10 & $1: r$ & (pH=V/9) $\mathrm{NH}_{r} \mathrm{HCO}_{r}$ + DTPA مولار + مولار & AB-DTPA \\
\hline r & 10 & $1: t^{x}$ & هـ & مهليج 1 \\
\hline ry & 0 & $1: 1 \circ$ & 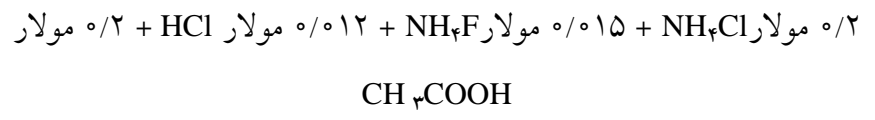 & مهليج \\
\hline ro & 0 & $1: 10$ & 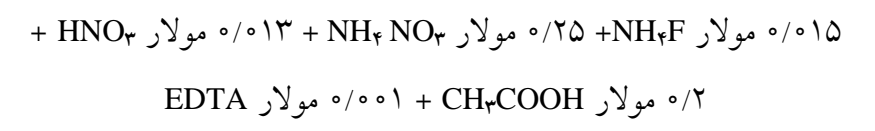 & مهليج r \\
\hline \&V & Iro & $1: 0$ & 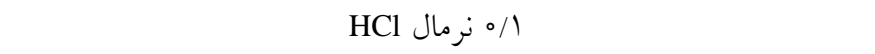 & $\mathrm{HCl}$ \\
\hline 10 & IYo & $1: 10$ & إم/ & $\mathrm{CaCl}_{r}$ \\
\hline
\end{tabular}

استان جهارمحال و بختيارى جمع آورى و به آزمايشگاه منتقل و

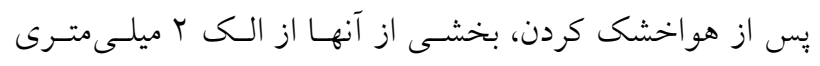
عبور داده شدند. در نهايت يس از انجام برخسى از تجزيسههـاى فيزيكى و شيميايى ه ا نمونه خـاك براسـاس مقــار روى قابـل

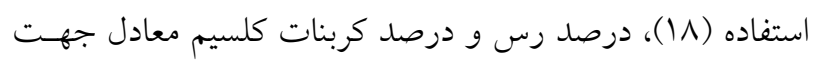
ادامه آزمايش انتخاب شدند.

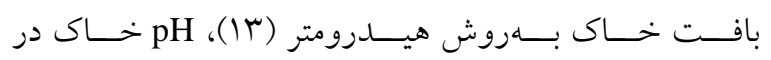

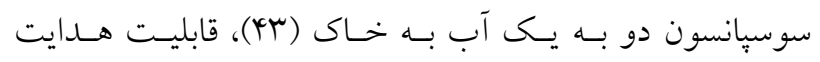
الكتريكى در عصساره دو بـه يـك آب بـه خـاك (باب)، كربنـات كلسيم معادل بهروش تيتراسيون بر گشتى (19)، كنجايش تبـادل

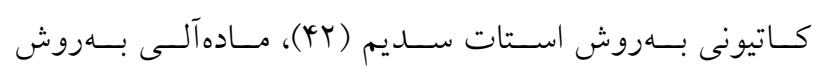
اكسيداسيون مرطوب (Yq) و روى قابل استفاده بـا اسـتفاده از ل روش عصاره گيرى شيميايى (جدول () تعيين شدند. مقدار كـل روى با استفاده از هضم با اسـيد نيتريـك ثل مـولار ( أل) تعيـين

\section{لجن فاضلاب}

لجن فاضلاب شهرى به صورت خشك از تصفيه خانه فاضـلاب شهركرد تهيه و از الك ا ميلى مترى عبور داده شد. خصوصسيات لجن فاضلاب شامل pH در سوسيانسيون يـنج بـه يـك آب بـه
كياه ضريب همبستخى برابر با "*1/1/ه گزارش كردند. منـدوزا و همكاران (Y4) به بررسى قابليت استفاده و جذب عناصر سنخين از جمله روى در خاكهاى تيمار شده با لجـن فاضـلاب تحـت كشت گياه سوركوم يرداختند. نتايج آنها نشان داد كه بين غلظت روى در كيـاه و روى عصــارهذيـرى شـــه بــا DTPA-TEA همبستكى معنى دارى وجود نداشت.

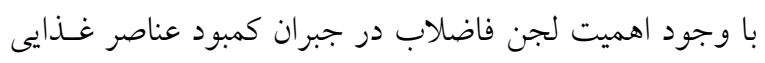
در خاكها، نياز به ارزيابى مقـدار قابـل اسـتفاده عناصـر غـذايى از جمله روى موجود در خاكهاى تيمار شده با لجن فاضلاب وجود دارد. مطالعه عصاره گير مناسب بـراى تعيـين مقــدار قابـل اسـتفاده روى در خاكهاى استان جهارمحسال و بختيـارى صـورت نخرفتـه است. اين تحقيق باتوجه به اهميت عنصر روى، امكـان استفاده از لجن فاضلاب براى جبران كمبود اين عنصر، اهميت كندم بهعنـوان

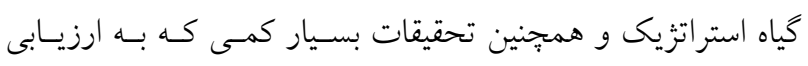
عصارهگير مناسب اين عنصر پرداخته است، انجام شد.

مواد و روش ها خصوصيات فيزيكى و شيميايى خاكها

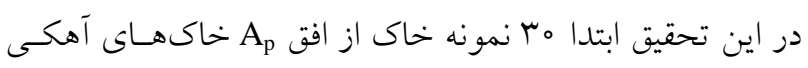


دماى Vo درجه سانتى گـراد در آون تهويـهدار خشـى و سـبس

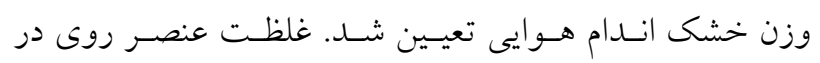

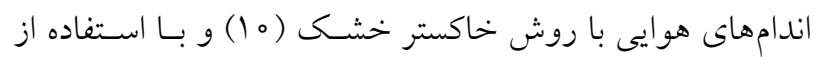

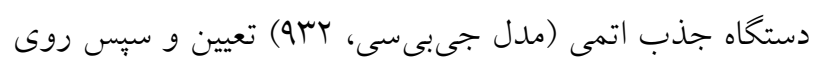
جذب شده با استفاده از رابطه زير محاسبه شد. عملكرد خشك (كيلو گرم در كلدان) × غلظت روى (ميلى گرم در كيلوكرم) = جذب روى (ميلى گرم در كلدان)

در هِايان ضريب همبستكى ساده (r) بين شاخصهـاى كيـاه

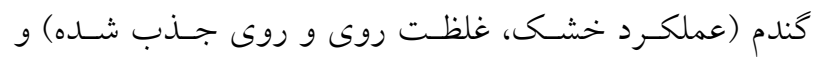

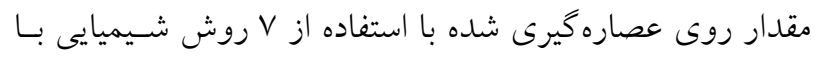

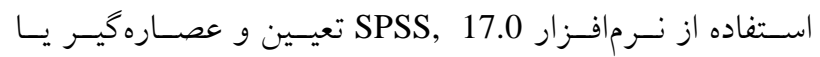

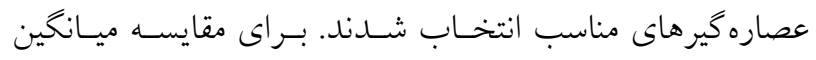

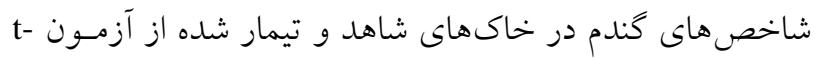
(P< استفاده شد.

\section{نتايج و بحث}

برخى از خصوصيات فيزيكى و شيميايى خاكهاى مورد مطالعه

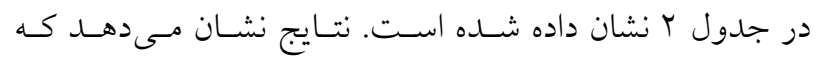
خصوصيات خاكها از دامنه تغييرات وسيعى برخـوردار بودنــد.

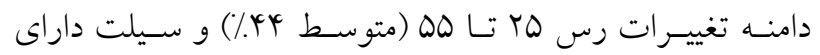

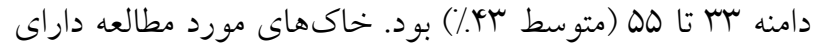
قH

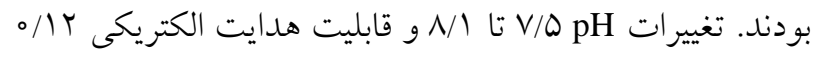

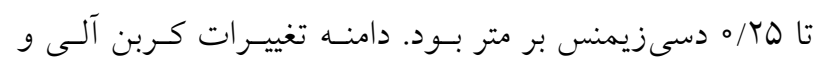

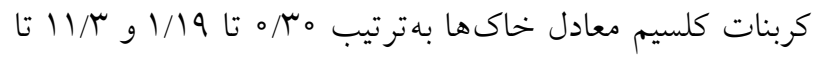

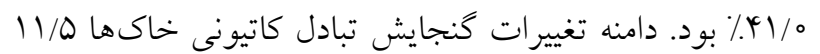

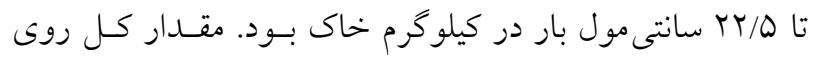

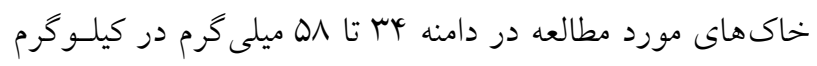

يميامدهاى كاربرد لجـن فاضـلاب در زمسينهـاى كشـاورزى

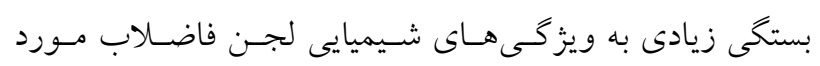

لجن فاضلاب، قابليت هدايت الكتريكى در عصاره بِنج بـه يـى

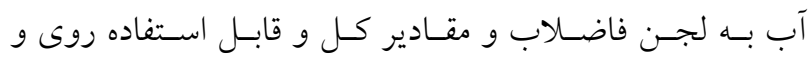

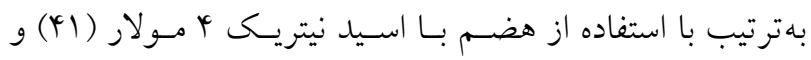
(1) DTPA-TEA

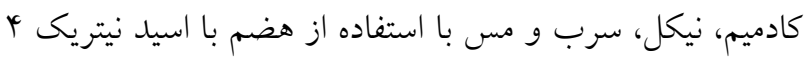

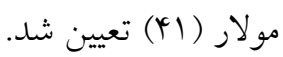

\section{كشت كلخانهاى}

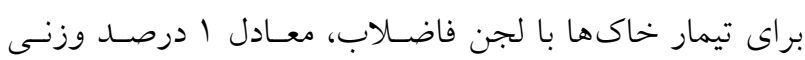

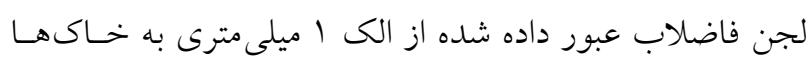

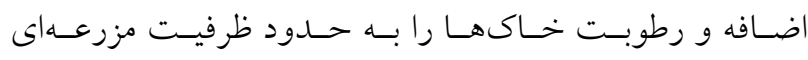

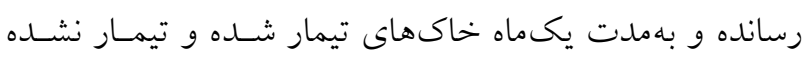

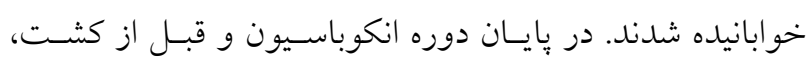

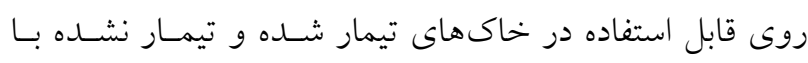

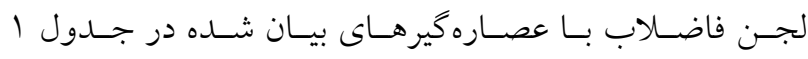

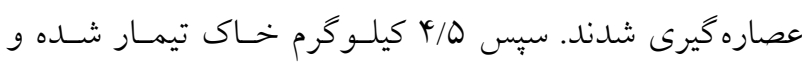

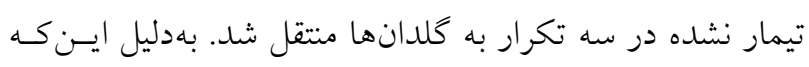

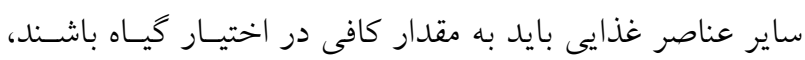
براساس نتايج تجزيه خاك به هر كلدان در خـاكهـاى شـاهد

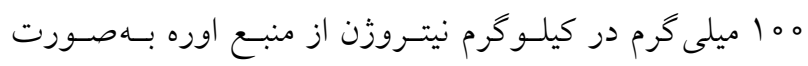

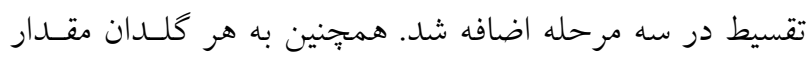

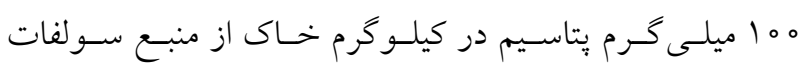

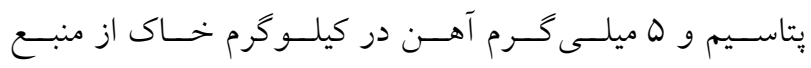

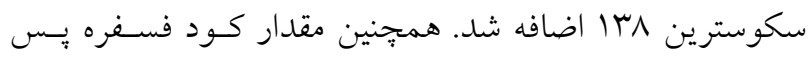

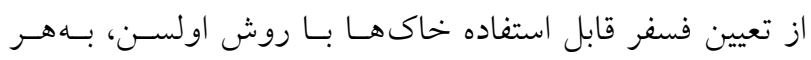
كلدان اضافه شد.

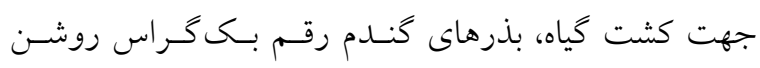

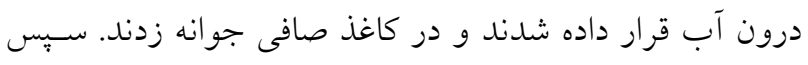

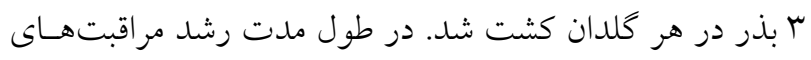

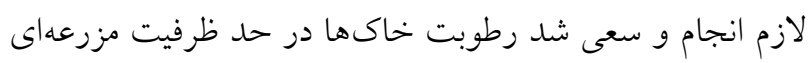

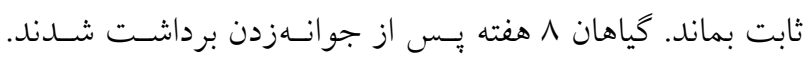

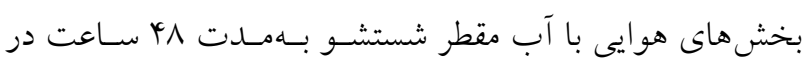


جدولr. برخى خصوصيات فيزيكى و شيميايى خاكهاى مورد مطالعه

\begin{tabular}{|c|c|c|c|c|c|c|c|c|}
\hline \multirow{2}{*}{$\begin{array}{c}\text { روى كل }) \\
\left(\mathrm{mg} \mathrm{kg}^{-1}\right)\end{array}$} & \multirow{2}{*}{$\begin{array}{c}\text { كنجايش تبادل كاتيونى } \\
\left.\text { (cmol } \mathrm{kg}^{-1}\right)\end{array}$} & \multirow{2}{*}{$\begin{array}{c}\text { هدايت الكتريكى } \\
\left(\mathrm{dS} \mathrm{m} \mathrm{J}^{-1}\right)\end{array}$} & \multirow{2}{*}{$\mathrm{pH}$} & كربن آلى & كربنات كلسيم معادل & سيلت & 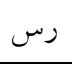 & \multirow{2}{*}{ شماره } \\
\hline & & & & & $(\%)$ & & & \\
\hline$\Delta V$ & $r \circ / q$ & $\circ / \mu$ & $\mathrm{V} / \mathrm{\Lambda}$ & $\circ / V Y$ & $r \Lambda / V$ & ro & $\Delta \Delta$ & 1 \\
\hline$\Delta Y$ & $19 / \pi$ & . & $\Lambda / 1$ & $\circ / \mu_{0}$ & $r \Delta / 9$ & py & or & r \\
\hline$i d$ & $T Y / D$ & $0 / 1 Y$ & $V / 9$ &.$/ 01$ & $r q / 4$ & $r q$ & $4 q$ & $r$ \\
\hline id & $r \mid / 9$ & $0 / 14$ & $\mathrm{~V} / \mathrm{\Lambda}$ & $\circ / V^{\prime}$ & $r G / 4$ & GY & 49 & r \\
\hline rv & $19 / 0$ & . & $1 / 1$ & O/QY & $r Y / Y$ & GT & 41 & 0 \\
\hline ky & $10 / 9$ & $0 / 19$ & $V / 9$ & $\circ / \Lambda \circ$ & $r Y / D$ & py & rV & 9 \\
\hline ry & $11 / 0$ & $0 / r 1$ & $\mathrm{~V} / \mathrm{V}$ & $0 / 4 V$ & $41 / 0$ & سM & TD & V \\
\hline$\Delta \wedge$ & $1 V / 9$ & $0 /$ TY & $1 / 1$ & $1 / 19$ & $r \mu / l$ & $\Delta \Delta$ & rᄉ & $\wedge$ \\
\hline$\Delta Y$ & $1 / / 0$ & $0 / T \Delta$ & $\mathrm{V} / \mathrm{\Lambda}$ & $1 / 19$ & $11 / \pi$ & 49 & $\uparrow \wedge$ & 9 \\
\hline$\Delta G$ & $1 V / 9$ & ס & $V / q$ & $\circ / 9 V_{0}$ & $1 \% / \Lambda$ & 49 & $4 q$ & 10 \\
\hline
\end{tabular}

استفاده دارد. pH لجن فاضلاب مورد استفاده ختثى (V/O) بـود. باشد (N). ميـانخين روى عصـاره گيـرى شـده در خـاكهـاى شـاهد،

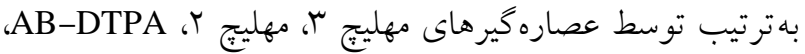
قابليت هدايت الكتريكى لجن فاضلاب T/YD دسـىزيمسنس بـر متر بود. مقدار روى قابل استفاده و روى كل در لجــن فاضـلاب I I DTPA-TEA

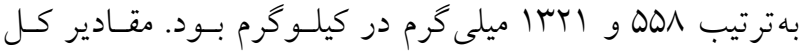
كاهش يافت. در خاكهاى تيمار شده با لجن فاضلاب، بهترتيب عصاره گيرهاى مهليج ب، DTPA-TEA AB-DTPA، مهليّج r.

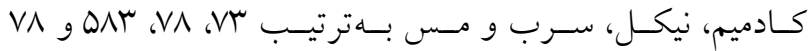
ميلى گرم در كيلو گرم بود. مقايسه مقادير عناصر سـنخين موجــود

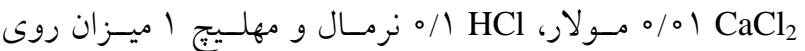
در لجن فاضلاب مورد استفاده با استانداردهاى آزانس حفاظـت بيشترى را استخراج نمودند. همانطوركه بيان شد براى تعيين مقدار قابل اسـتفاده عنصـر غذايى روى در خاكها روشهاى عصارهذيـرى مختلفـى مانـــد محلولهاى نمكى، كلات كنندههـا و اسـيدها وجـود دارد (هم). توانايى عصاره كيرها در استخراج عناصر متفاوت است. توانـايى زياد عصاره گيــ مهلـيج ب در عصـارهذيـرى مقـدار بيشـتر روى بهدليل وجود كـلات كنــده اتـيلن دى آمسين تـــا اسـتيك اسـيد (EDTA)

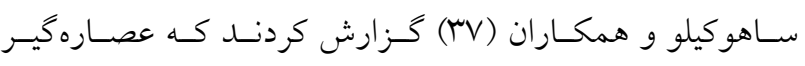
pH بلدون توجه به خصوصيات خــاك بـهدليـل داشـن EDTA كمتر نسبت بـه عصـارهگيـر DTPA مقـدار بيشـترى از عناصـر

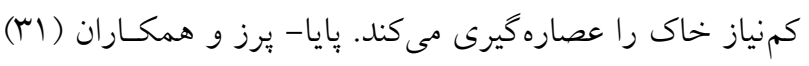
محيط زيست آمريكا (USEPA) نشان داد كـهـ غلظـت كـادميم و سرب در لجن فاضلاب بيشتر از مقدار استاندارد ايسن عناصـر بهترتيب هبو وهم ميلى گرم در كيلو گرم) بود (هQ (Y).

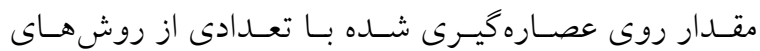
شيميايى كه براى تعيين روى قابل اسـتفاده بـهـكـار رفتـهانـد در

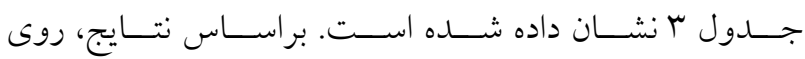
عصاره كيرى شده با روش هاى مختلف در يـك خـاك تغييـرات زيادى داشت كه نشاندهنده مكانيسم متفاوت عصـاره كيرهـا در استخراج اين عنصر اسـت. همجنـين در هـر عصـاره گيـر، روى عصـارهذيـرى شــده در خـاكهــا تفــاوت زيـادى داشـت كـهـ نشاندهنده تفاوت روى قابل عصارهگيرى در خاكها اسـت كـه. مى تواند ناشى از تفاوت در اجزاء معدنى ايسن عنصـر در خـاك 
فاضلاب به خاك، مقــار قابـل استفاده عنصـر روى افـزايش

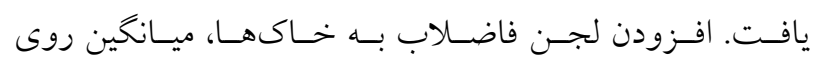

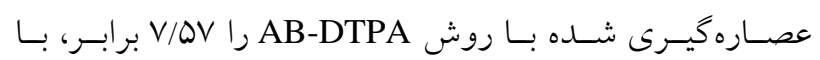

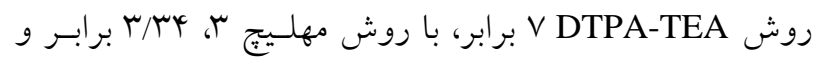

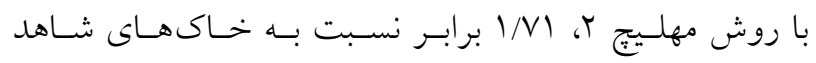

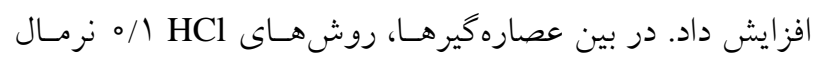

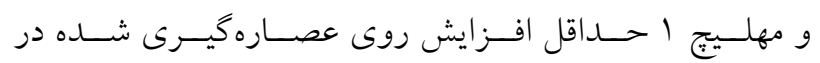

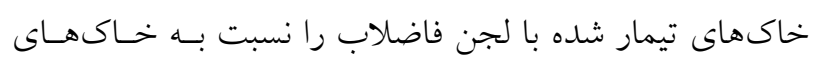

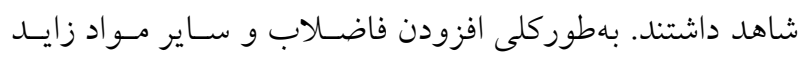

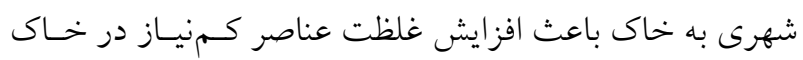

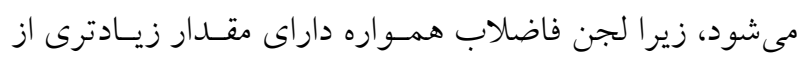

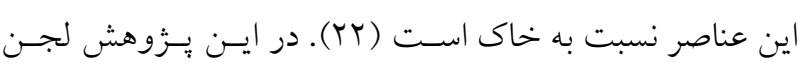

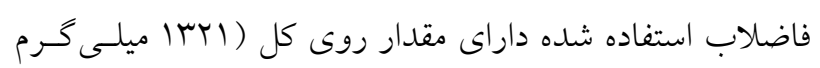

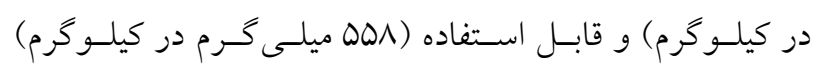

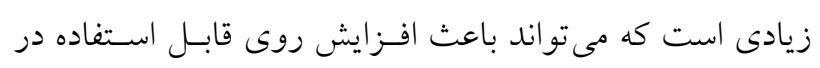
خاكهاى تيمار شده با لجن فاضلاب شود. كرمسى و همكـاران (IV)

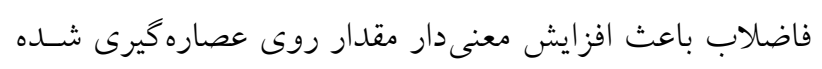

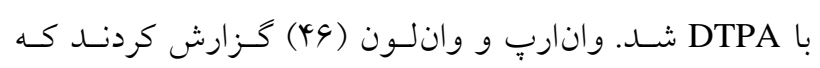

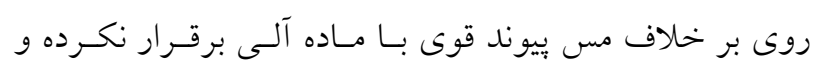

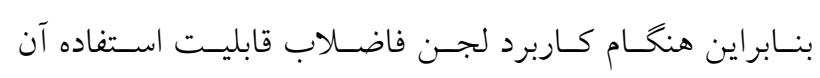

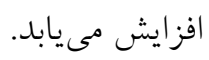
جدول ب شـاخص هـاى كيـاه گنــدم را در ما اخـاك مـورد

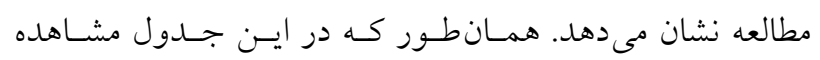

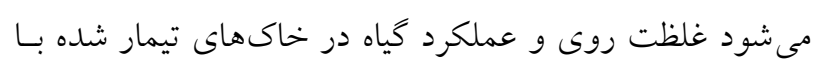

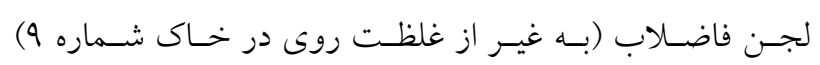

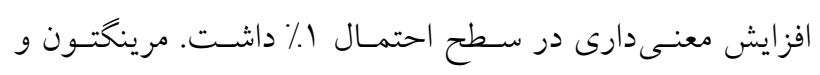

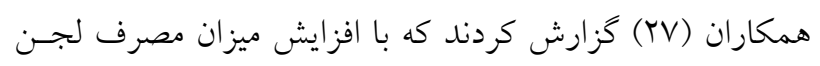

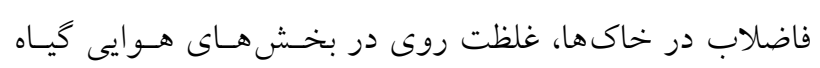

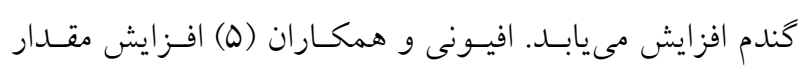
جذب روى به وسيله كياهان كـاهو و اسـفناج در اراضسى تيمـار شده با لجن فاضلاب را كزارش كردند. موررا و همكـاران (YN)
نشان دادند كـه عصـارهذيـر EDTA توانـايى اسـتخراج عناصـر

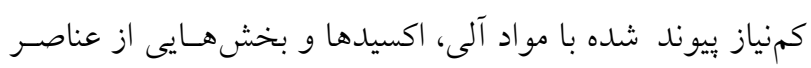

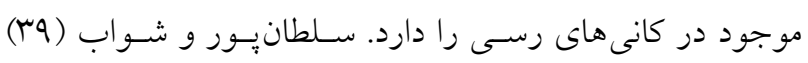

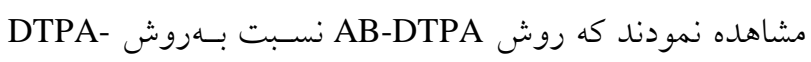

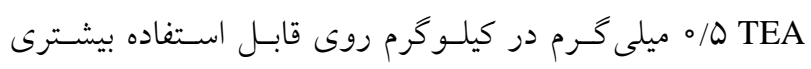

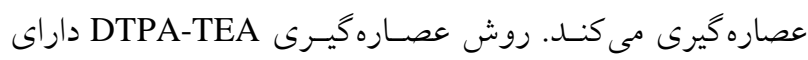

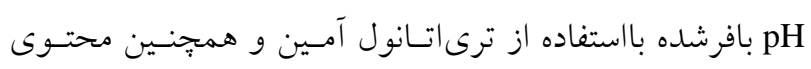

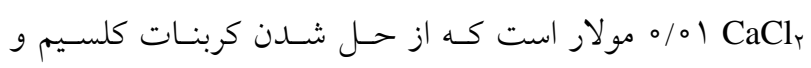
آزادشدن عناصر محبوس شده در اين تركيب جلو گيرى مى كنــ

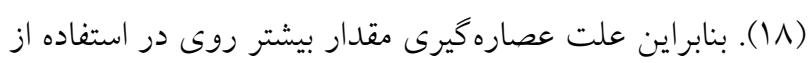

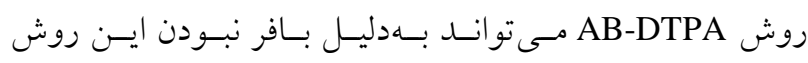

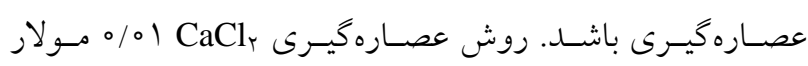

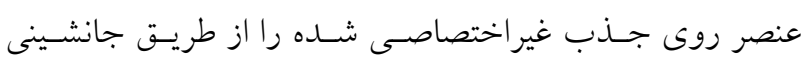

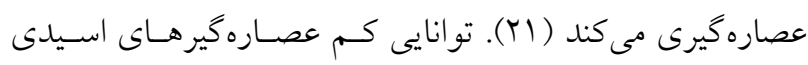

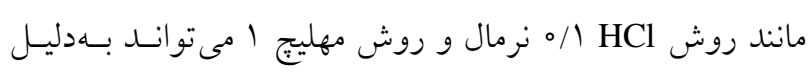

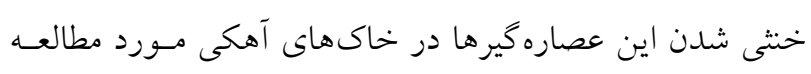

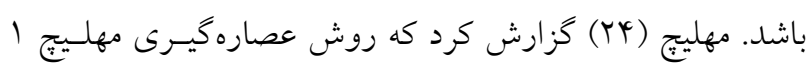

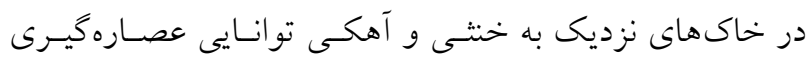

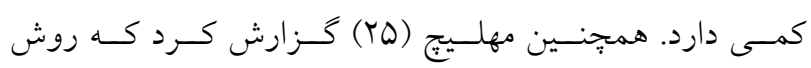

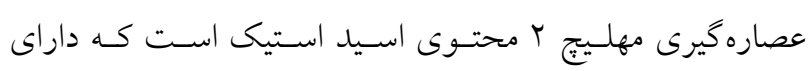
قدرت بافرى بيشترى نسبت به اسيدهاى مورد استفاده در روش مهري

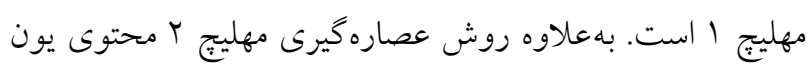

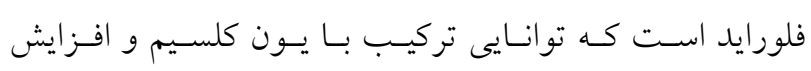

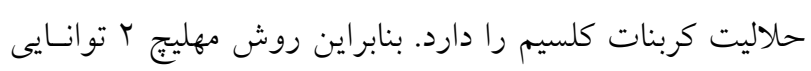

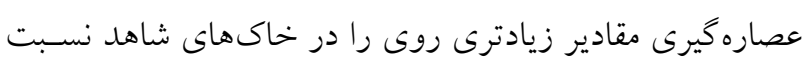

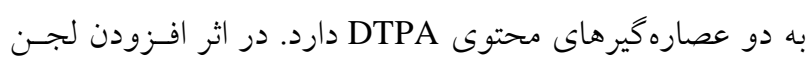

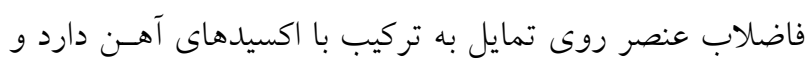

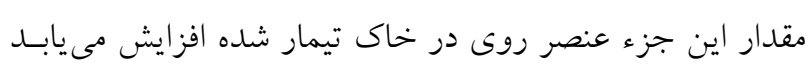

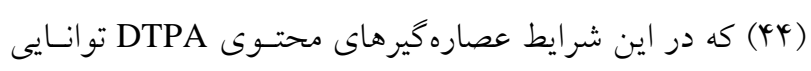

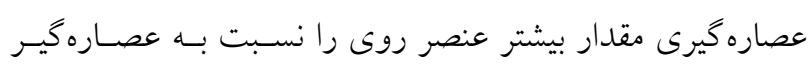
مهليج r دارند.

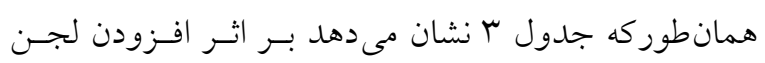




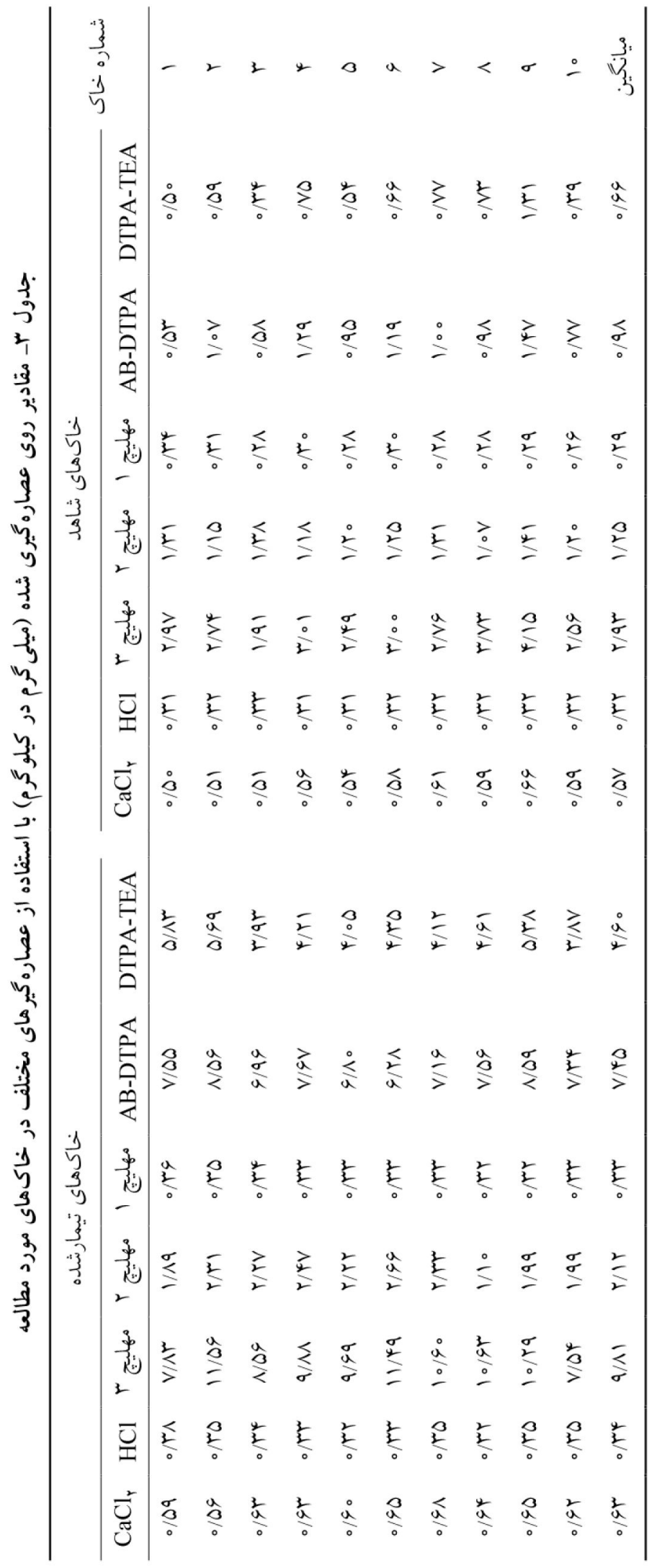


جدول F. شاخصهاى گياه گندم در خاكهاى مورد مطالعه

\begin{tabular}{|c|c|c|c|c|c|c|}
\hline \multicolumn{3}{|c|}{ خاكهاى تيمارشده } & \multicolumn{3}{|c|}{ خاكهاى شاهد } & \multirow[b]{2}{*}{$\begin{array}{l}\hat{G} \\
\bar{r} . \\
\stackrel{0}{\grave{\xi}}\end{array}$} \\
\hline 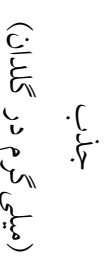 & $\begin{array}{ll}\frac{c}{c} & \\
\check{\varepsilon} & \tilde{c} \\
\check{c} & \xi \\
\breve{c}_{11} & \xi\end{array}$ & 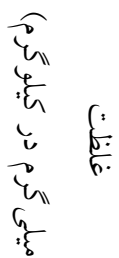 & 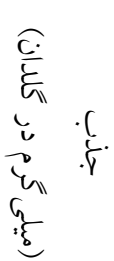 & 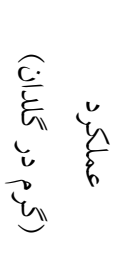 & 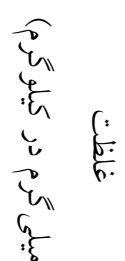 & \\
\hline o/lr & $\Delta / V T$ & $T \mu / T_{0}$ & $0 / 09$ & $4 / 19$ & $\mid x / r_{0}$ & 1 \\
\hline$\circ / 1 \wedge$ & $9 / \mu V$ & YN/Y。 & $0 / 1 T$ & $G / V D$ & $I V / A D$ & r \\
\hline $0 / T \Lambda$ & N/AT & \% & $0 / 09$ & $\Delta / V V$ & $19 / 40$ & r \\
\hline O/KY & $9 / 90$ & $Y Y / I V$ & $O / Y^{Y}$ & $9 / 04$ & $\mathrm{rq/90}$ & $\varphi$ \\
\hline $0 / T \Lambda$ & N/VG & 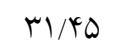 & $0 / 11$ & D/AT & $1 N / T 0$ & 0 \\
\hline $0 / 49$ & $\mathrm{~V} / \mathrm{AM}$ & TY/VO & $0 / 11$ & $r / \mu 1$ & $Y \Psi / A V$ & 9 \\
\hline $0 / 79$ & $\Lambda / \Delta \circ$ & $m \pi / 90$ & $0 / 10$ & $\varphi / \mu r$ & سM/AT & V \\
\hline$\circ / \wedge$ & $9 / 9 T$ & $r \Delta / V_{0}$ & $0 / 14$ & $9 / 19$ & $r \circ / T Q$ & $\wedge$ \\
\hline س & $11 / 21$ & 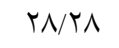 & $\circ / T \Delta$ & $\Lambda / V Y$ & $r \Lambda / r_{0}$ & 9 \\
\hline $0 / 19$ & $V / V Q$ & $Y Y / Y$ O & $0 / 11$ & $4 / 10$ & $I V / Y_{0}$ & 10 \\
\hline$\circ / T \Delta^{a}$ & $1 / 19^{a}$ & $\mu \circ / \mu_{\circ} a$ & $\circ / / \mu^{\mathrm{b}}$ & $\Delta / \wedge q^{b}$ & 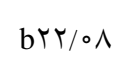 & *ميانخين \\
\hline
\end{tabular}

همبستخى بين روى عصارهگيرى شده با روش AB -DTPA بـا شاخصهاى غلظت روى و جذب روى بهترتيـب (9/ه و 91/ه

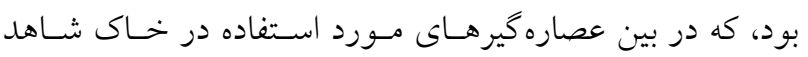

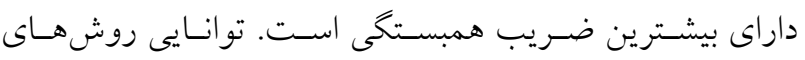
عصارهيرى حاوى كلات كندهها در تحقيقـات بسيارى جهـت

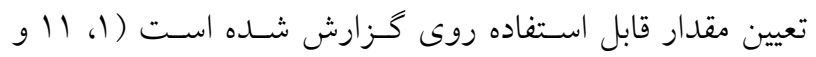

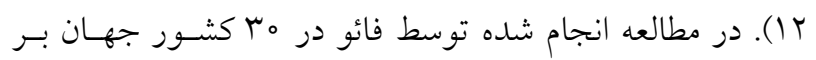

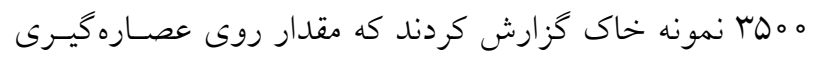

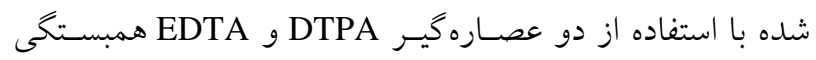

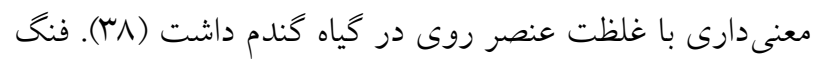

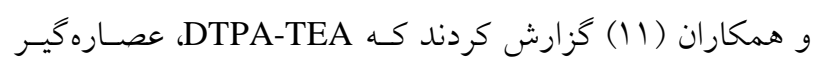

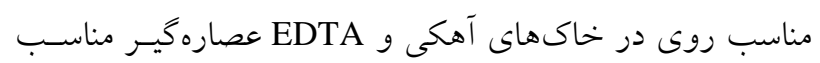

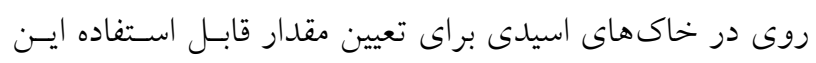

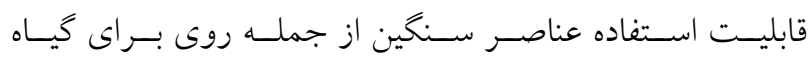

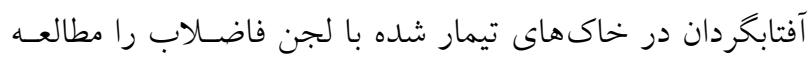

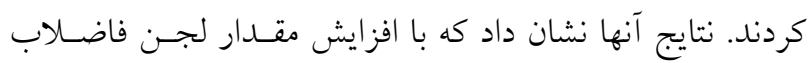

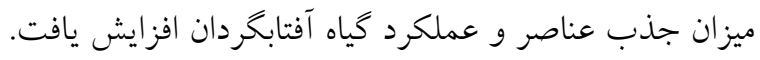

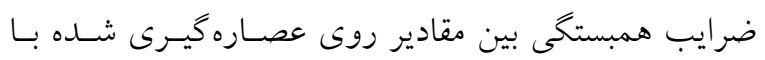

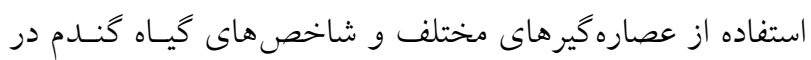

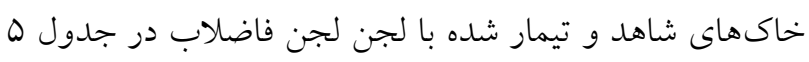

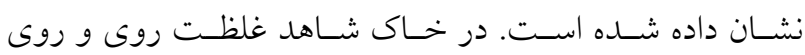

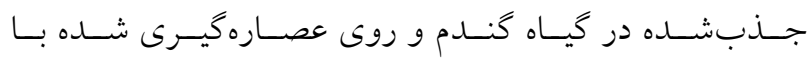

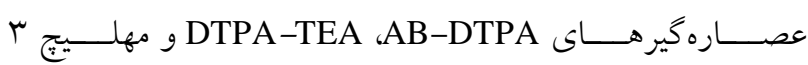

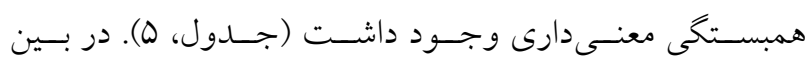

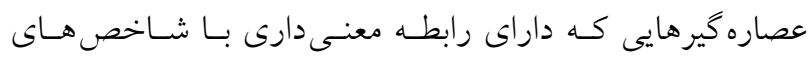

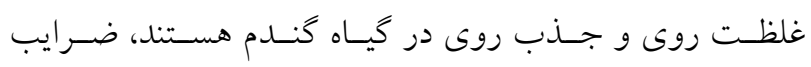


جدول ه. ضريب همبستخى (r) بين مقادير روى عصاره گيرى شده با عصاره گيرهاى مختلف و شاخصهاى گياه گندم

\begin{tabular}{|c|c|c|c|c|c|c|c|}
\hline $\mathrm{CaCl}_{r}$ & $\mathrm{HCl}$ & مهليج r & مهليج & مهليج & AB -DTPA & DTPA -TEA & شاخصهاى گياه \\
\hline & & & \multicolumn{2}{|c|}{ خاكهاى شاهد } & & & \\
\hline.$/ 90^{*}$ & $-0 / 19^{\mathrm{ns}}$ & $\circ / 9 V^{*}$ & $-\circ / 1 \circ \mathrm{ns}$ & $\circ / 091 \mathrm{~ns}$ & $\circ / 91^{* *}$ & $\circ / \wedge V^{* *}$ & غلظت \\
\hline$\circ / \mathcal{F} V^{n s}$ & $\circ / \circ r^{n s}$ & $\circ / \mu y \mathrm{~ns}$ & $-0 / r_{G} \mathrm{~ns}$ & $-\circ / \mu V^{n s}$ & $0 / \mathcal{C H}_{\mathrm{r} s}$ & $0 / \mu y \mathrm{~ns}$ & عملكرد \\
\hline \multirow[t]{2}{*}{$\circ / 0 \circ \mathrm{ns}$} & $-0 / 19^{\mathrm{ns}}$ & $0 / 99^{*}$ & -o/rG ns & $\circ / \circ$ rns & $\circ / \wedge 9^{* *}$ & $0 / 99^{*}$ & جذب \\
\hline & & & \multicolumn{2}{|c|}{ خاكهاى تيمارشده } & & & \\
\hline$\circ / \wedge^{\mathrm{ns}}$ & $-\circ / \mathbb{F}^{\mathrm{ns}}$ & $\circ / T \Lambda^{\mathrm{ns}}$ & 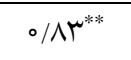 & $0 / / Y^{\mathrm{ns}}$ & $-0 / Y^{\mathrm{ns}}$ & $-\circ / V^{n s}$ & غلظت \\
\hline - $/ \Delta \mu^{n s}$ & $-\circ / \mathbb{\varphi}_{\circ} \mathrm{ns}$ & $-0 / 0 y^{\mathrm{ns}}$ & $\circ / \Gamma \Delta^{n s}$ & $-\circ / \varphi_{\circ} \mathrm{ns}$ & $\circ / \circ Y^{\mathrm{ns}}$ & $-\circ / V^{n s}$ & عملكرد \\
\hline$\circ / \Delta \Delta^{\mathrm{ns}}$ & - & $-\circ / \circ \wedge^{\mathrm{ns}}$ & $0 /$ ky ns & $-\circ / T V^{n s}$ & $\circ / \circ Y^{\mathrm{ns}}$ & - & جذب \\
\hline
\end{tabular}

روى قابل استفاده در خاكهاى تيمار شده با لجـن فاضـلاب را

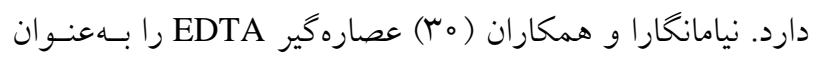
مناسب ترين عصاره گير روى در خاكهاى تيمار شــه بـا لجـن فاضلاب كزارش كردند. بيو و همكاران (Yr) بـه ارزيسابى تـوان عصسارهگيرهـاى r NaNOr سنخين از جمله روى در ده خاك تيمار شده با لجـن فاضـلاب

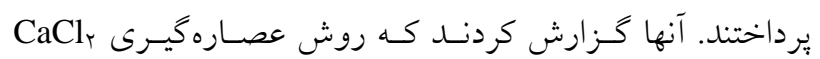
1 / مولار توانايى بيشترى در استخراج روى نسـبت بـه سـاير عصاره كيرهاى مورد استفاده در اين تحقيـق داشـت. آنهـا علـت اين يديــه را توانـايى يـون كلسـيم در جانشـينى يـون روى در سايتهاى تبادلى در مقايسه با يونهـاى يـك ظرفيتى كـزارش

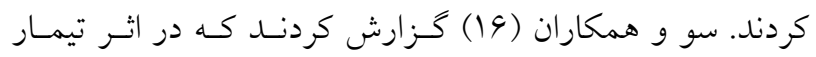
خاى با لجن فاضلاب جزءهاى تبادلى و بيوندشده با اكسيدهاى آهن و منگنز عناصر سنخين افزايش مى يابد. آنها كزارش كردنـد كه در طى انكوباسيون خاى با لجـن فاضـلاب، عنصـر روى از جزء بيوندشده با كربناتها آزاد و هم:جنين در نتيجه تجزيه مواد

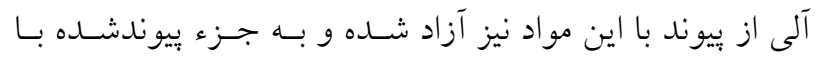

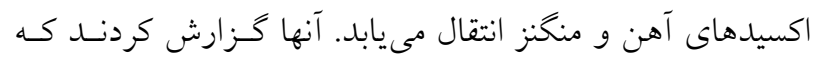
توانايى عصاره گير DTPA براى عصاره گيـرى روى بيونــ شــده

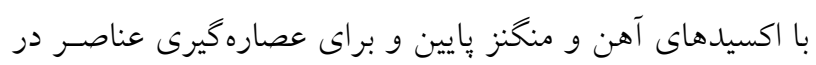

عنصر در گياه كندم بود. اردلان و همكاران ( (1) كـزارش كردنـــ

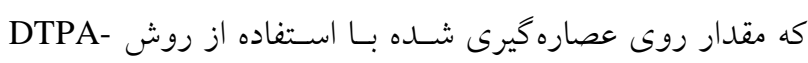
توانايى برآورد غلظت روى در كياه ذرت را داشت. رويـا و شو كلا (هم) در مطالعهاى بـه بررسـى و انتخـاب عصـارهذيـر مناسب در ^ خاى تحت كشت كياه برنج در كشـور هندوسـتان

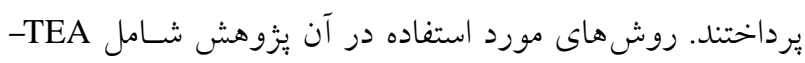

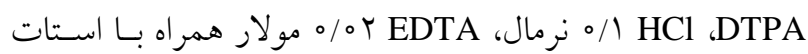

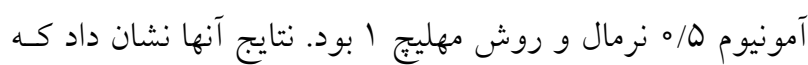
روش عصاره گيرى DTPA-TEA مناسب تـرين عصـارهگيـر در برآورد روى قابل استفاده بود. از بين عصاره گيرهاى استفاده شده در خاكهاى تيمار شـده با لجن فاضلاب، فقط بـين روى عصـاره گيـرى شـده بـا روش

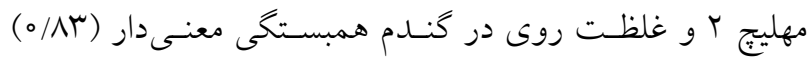
وجود داشت (جدول ه). در تحقيقات انجـام شــه، يـى روش عصاره گيرى بهعنوان بهترين روش تعيسين مقـدار قابـل اسـتفاده عنصر روى در خاكهاى تيمار شده با لجـن فاضـلاب كـزارش نشده است. كرمى و همكاران (IV) گزارش كردند كـه ضـريب همبستخى بين روى عصارهذيرى شــده بـا اسـتفاده از DTPA از خاكهاى آهكى تيمار شده با لجن فاضلاب و روى جذب رون شده

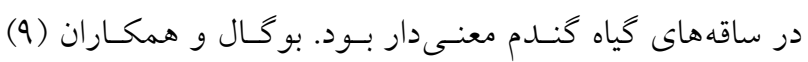
گزارش كردند كه عصارهگير NH+NOr 


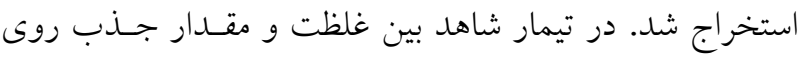
در گياه و عصاره گيرهاى DT-DTPA، DTPA-TEA و مهلـيج r همبستخى معنى دارى وجود داشت. در بين عصاره گيرهايى كه داراى رابطه معنى دارى با شاخص هاى غلظت و جـــب روى در كياه هستند، عصاره گيـر AB-DTPA بـا شـاخص غلظـت و بـاس شـاخص جـــب روى بيشـترين همبسـتكى را داشـت. در بـين عصاره گيرهاى مختلف مورد استفاده در خاكهاى تيمار شده بـا لجن فاضلاب، فقط بين روى عصارهگيرى شده با روش مهلـيج r و شاخص غلظت همبستخى معنى دار وجود داشـت. ضـريب همبستخى (r) بايين و غيرمعنى دار عصارهگيرهاى حاوى DTPA در خاكهاى تيمار شده با لجن فاضلاب بين مقدار قابل استفاده روى و شاخص هاى گياه گندم مىتواند بهدليل عدم توانايى ايسن

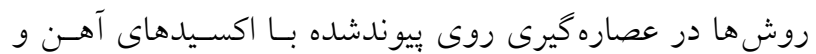
منخنز و آزاد شدن كند باشد.
جزءهاى محلول، تبادلى و بيوندشده بـا مـواد آلى در خـاكهـا

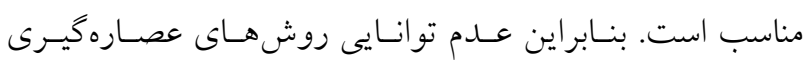
حاوى كلات كنندهها در خاكهاى تيمار شده با لجن فاضـلاب در تعيـين مقـدار قابـل اسـتفاده عنصـر روى بــراى گيـاه گنــدم مى تواند بهدليل عدم توانايى اين روشها در عصارهيــى روى

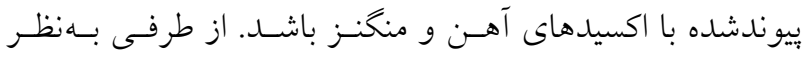
مىرسد كه عصاره كير مهليج r شامل تركيباتى است كه توانـايى بيشترى در عصاره گيرى روى از جزءهاى تبادلى و بيوند شده با اكسـيدهاى آهـن و منگنـز دارد. در ايسن ارتبـاط بـه تحقيقـات بيشترى نياز است.

\section{نتيجه گيرى}

نتايج اين يـزَوهش نشـان داد غلظـت روى و عملكــرد گيـاه در خاكهاى تيمار شده با لجن فاضلاب افزايش معنسىدار داشـت. بيشترين مقدار روى عصارهذيرى شـده در خـاكهـاى شـاهد و تيمار شده، با روش مهلسيج با و كمتسرين آن بـا روش مهلـيج

\section{منابع مورد استفاده}

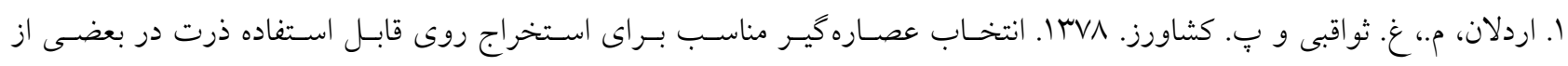

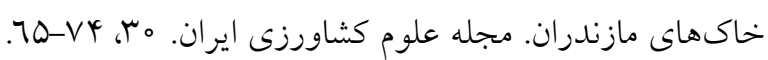

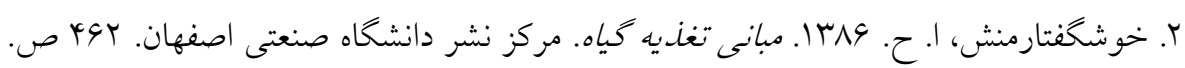

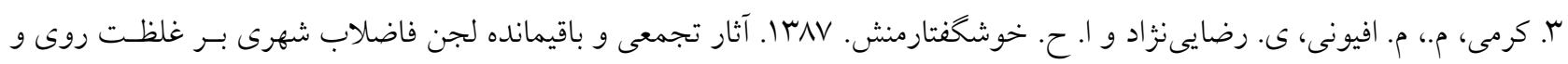

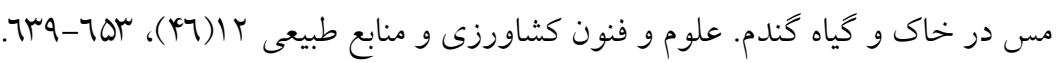

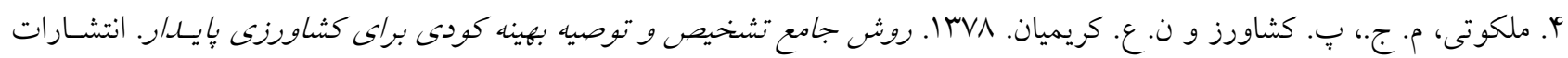
دانشخاه تربيت مدرس.

5. Afyuni, M., Y. Rezaeinejad and R. Schulin. 2006. Extractability and plant uptake of $\mathrm{Cu}, \mathrm{Zn}, \mathrm{Pb}$ and $\mathrm{Cd}$ from a sludge - amended Haplargid in Central Iran. Arid Land Res. Manag. 20: 29-41.

6. Aggelides, S. M. and P. A. Londra. 2000. Effect of compost produced from town wastes and sewage sludge on the physical properties of a loamy and a clay soil. Bioresour. Technol. 71: 253-259.

7. Allowoy, B. J. 1990. Heavy Metals in Soils. Blackie and Son Ltd. Glascow and London. p. 339.

8. Alvarez, J. M., L. M. Lopez-Valdivia, J. Novillo, A. Obrador and M. I. Rico. 2006. Comparison of EDTA and sequential extraction tests for phytoavailability prediction of manganese and zinc in agricultural alkaline soils. Geoderma 132: 450-463.

9. Bhogal, A., F. A. Nicholson, B. J. Chambers and M. A. Shepherd. 2003. Effects of past sewage sludge additions on heavy metal availability in light textured soils: implications for crop yields and metal uptakes. Environ. Pollut. 121: 413-423.

10. Campbell, C. R. and C. O. Plank. 1998. Preparation of plant tissue for laboratory analysis. PP. 37-50. In: Kalra, Y.P. (Ed.), Handbook of Reference Methods for Plant Analysis. CRC Press, Taylor \& Francis Group. 
11. Feng, M. H., X. Q. Shan, S. Z. Zhang and B. Wen. 2005. Comparison of a rhizosphere-based method with other one-step extraction methods for assessing the bioavailability of soil metals to wheat. Chemosphere 59: 939-949.

12. Fuentes, A., M. Llorens, J. Saez, A. Soler, M. I. Aguilar, J. F. Ortuno and V. F. Meseguer. 2004. Simple and sequential extractions of heavy metals from different sewage sludges. Chemosphere 54: 1039-1047.

13. Gee, G. W. and J. W. Bauder. 1986. Particle size analysis. PP. 404-407. In: Klute, A. (Ed.), Methods of Soil Analysis. Part 1. $2^{\text {nd }}$ edition. Agron. Monogr. 9. ASA and SSSA, Madison, WI.

14. Gupta, A. K. and S. Sinha. 2007. Assessment of single extraction methods for the prediction of bioavailability of metals to Brassica juncea L. Czern. (var. Vaibhav) grown on tannery waste contaminated soil. J. Hazd. Mater. 149: $144-150$

15. Hoyt, P. B. and M. Nyborg. 1971. Toxic metals in acid soil: 2. Estimation of plant available manganese. Soil Sci. Soc. Am. Proc. 35: 141-144.

16. Hseu, Z. H. 2006. Extractability and bioavailability of zinc over time in three tropical soils incubated with biosolids. Chemosphere, 63: 762-771.

17. Karami, M., M. Afyuni, Y. Rezainejad and R. Schulin. 2009. Heavy metal uptake by wheat from a sewage sludgeamended calcareous soil. Nutr. Cycl. Agroecosyst 83: 51-61.

18. Lindsay, W. L. and W. A. Norvell. 1978. Development of a DTPA soil test for zinc, iron, manganese, and copper. Soil Sci. Soc. Am. J. 42: 421-428.

19. Loeppert, R. H. and D. L. Suarez. 1996. Carbonate and gypsum. PP. 437-474. In: Sparks, D. L. (Ed.), Methods of Soil Analysis. SSSA, Madison.

20. Malakouti, M. J. 2007. Zinc is a neglected element in the life cycle of plants. Middle Eastern \& Russian J. of Plant Sci. and Biotechnology 1(1): 1-12.

21. Martenz, D. C. and W. L. Lindsay. 1990. Testing soils for copper, iron, manganese and zinc. PP. 229-264. In: Westrman, R.L. (Ed.), Soil Testing and Plant Analysis. SSSA. Madison. Wisconsin, USA.

22. McGrath, S. P., F. J. Zhao, S. J. Dunhum, A. R. Crosland and K. Coleman. 2000. Long-term changes in the extractability and bioavailability of zinc and cadmium after sludge application. J. Environ. Qual. 29:87-883.

23. Mehlich, A. 1953. Determination of $\mathrm{P}, \mathrm{Ca}, \mathrm{Mg}, \mathrm{K}, \mathrm{Na}$ and $\mathrm{NH}_{4}$. North Carolina Soil Testing Div. Mimeo, Raleigh.

24. Mehlich, A. 1978. New extractant for soil test evaluation of phosphorus, potassium, calcium, magnesium, sodium, manganese and zinc. Commun. Soil Sci. Plant Anal. 9: 477-492.

25. Mehlich, A. 1984. Mehlich 3 soil test extractant: A modification of Mehlich 2 extractant. Commun. Soil Sci. Plant Anal., 15: 1409-1416.

26. Mendoza, J., T. Garrido, G. Castillo and N. San-Martin. 2006. Metal availability and uptake by sorghum plants grown in soils amended with sludge from different treatments. Chemosphere 65: 2304-12.

27. Merrington, G., L. Winder and I. Green. 1997. The bioavailability of Cd and Zn from soils amended with sewage sludge to winter wheat and subsequently to the grain aphid Sitobionavenae. Sci. Total Environ. 205: 245-254.

28. Morera, M. T., J. Echeverria and J. Garrido. 2002. Bioavailability of heavy metals in soils amended with sewage sludge. Can. J. Soil Sci. 82: 433-438.

29. Nelson, D. W. and L. E. Sommers. 1996. Carbon, organic carbon, and organic matter. PP. 961-1010. In: Sparks, D.L. (Ed.), Methods of Soil Analysis. SSSA, Madison.

30. Nyamangara, J. and J. Mzezewa. 1999. The effect of long-term sewage sludge application on $\mathrm{Zn}, \mathrm{Cu}, \mathrm{Ni}$ and $\mathrm{Pb}$ levels in a clay loam soil under pasture grass in Zimbabwe. Agric. Ecosys. Environ. 73: 199-204.

31. Paya-Perez, A., J. Sala and F. Mousty. 1993. Comparison of ICPAES and ICP-MS for the analysis of trace elements in soil extracts. Int. J. Environ. Anal. Chem. 51: 223-230.

32. Pueyo, M., G. Rauret, D. Luck, M. Yli-Halla, H. Muntau, P. Quevauville and J. F. Lopez-Sanchez. 2004. Assessment of $\mathrm{CaCl}_{2}, \mathrm{NH}_{4} \mathrm{NO}_{3}$ and $\mathrm{NaNO}_{3}$ extraction procedures for the study of $\mathrm{Cd}, \mathrm{Pb}$ and $\mathrm{Zn}$ extractability in contaminated soils. Anal. Chim. Acta. 504: 217-226.

33. Ramachandran, V. and T. J. D’Souza. 1998. Plant uptake of cadmium, zinc, and manganese in soils amended with sewage sludge and city compost. Bull. Environ. Contam. Toxicol. 61: 347-354.

34. Rhoades, J. D. 1996. Salinity: electrical conductivity and total dissolved solids. PP. 417-435. In: Sparks, D. L. (Ed.), Methods of Soil Analysis. SSSA, Madison. 35. Rupa, T.R. and L.M. Shukla. 1999. Comparison of four extractants and chemical fractions for assessing available zinc and copper in soils of India. Commun. Soil Sci. Plant Anal. 30: 2579-2591.

36. Saffari, M., J. Yasrebi, N. Karimian and X. Q. Shan. 2009. Evaluation of three sequential extraction methods for fractionation of zinc in calcareous and acidic soils. Research J. of Biological Sci. 4: 848-857.

37. Sahuquillo, A., A. Rigol and G. Rauret. 2003. Overview of the use of leaching/extraction tests for risk assessment of trace metals in contaminated soils and sediments. Trend Anal. Chem. 22: 152-159.

38. Sillanpaa, M. 1982. Micronutrients and the nutrient status of soils. A global study. FAO Bull. 48.

39. Soltanpour, P. N. and A. P. Schwab. 1977. A new soil test for simultaneous extraction of macro- and micro- 
nutrients in alkaline soils. Commun, Soil, Sci. Plant Anal. 8: 195-207.

40. Sommers, L. E. 1977. Chemical composition of sewage sludges and analysis of their potential use as fertilizers. J. Environ. Qual. 6: 225-231.

41. Sposito, G. L., J. Lund and A. C. Chang. 1982. Trace metal chemistry in arid-zone field soils amended with sewage sludge: I. Fractionation of Ni, Cu, Zn, Cd, and Pb in solid phases. Soil Sci. Soc. Am. J. 46: 260-265.

42. Sumner, M. E. and P. M. Miller. 1996. Cation exchange capacity and exchange coefficient. PP. 1201-1230. In: Sparks, D.L. (Ed.), Methods of Soil Analysis. SSSA, Madison.

43. Thomas, G. W. 1996. Soil pH and soil acidity. PP. 475-490. In: Sparks, D.L. (Ed.), Methods of Soil Analysis. SSSA, Madison.

44. Torri, S. I. and R. Lavado. 2008. Zinc distribution in soils amended with different kinds of sewage sludge. J. Environ. Manage. 88: 1571-1579.

45. USEPA. 1993. Clean water act. Section 503. Vol. 58, No. 32, USEPA. Washington, DC.

46. Van Erp, P. J. and P. Van Lune. 1991. Long-term heavy metal leaching from soils-sewage sludge and soil/sewage mixtures. Environ. Sci. Technol. 25: 706-711.

47. Wollan, E. and P. H. T. Beckett. 1979. Changes in the extractability of heavy metals on the interaction of sewage sludge with soil. Environ. Pollut. 20: 215-30. 


\title{
Assessment of Several Extractants for the Determination of Wheat- available Zn (Triticum aestivum L.) in Calcareous Soils Amended and Unamended with Sewage Sludge
}

\author{
H. R. Motaghian*, A. R. Hosseinpur, J. Mohammadi and F. Raiesi ${ }^{1}$
}

(Received: Nov. 28-2011; Accepted : Nov. 28-2012)

\begin{abstract}
Zinc $(\mathrm{Zn})$ is one of the essential micronutrients for plant growth and its deficiency frequently occurs in calcareous soils. But, a suitable extractant for estimation of plant-available $\mathrm{Zn}$ in calcareous soils, amended with sewage sludge, has not been presented yet. The aim of this research was to assess several chemical extractants (7 extractants) for estimation of available $\mathrm{Zn}$ in calcareous soils amended $(1 \% \mathrm{w} / \mathrm{w})$ and unamended with sewage sludge. Results showed that Mehlich 3 and Mehlich 1 extractants extracted the highest and the lowest concentrations of $\mathrm{Zn}$ in both amended and unamended soils, respectively. All wheat indices (wheat yield, Zn concentration and Zn uptake) increased by sewage sludge addition. Besides, the results indicated that in unamended soils, significant correlations were found $\left(\mathrm{r}=0.65^{*}-0.91^{* *}\right)$ between extracted Zn using AB-DTPA, DTPA-TEA and Mehlich 3 extractants and different wheat indices. On the contrary, in sewage sludge-amended soils, only the correlation between extracted $\mathrm{Zn}$ using Mehlich 2 and $\mathrm{Zn}$ concentration was significant $\left(\mathrm{r}=0.83^{* *}\right)$. According to this study findings, the suitable extractant for extracting wheatavailable $\mathrm{Zn}$ is thoroughly different in calcareous soils amended and unamended with sewage sludge.
\end{abstract}

Keywords: Sewage sludge; Zn extracants; Wheat.

1. Dept. of Soil Sci., College of Agric., Shahrekord Univ., Shahrekord, Iran.

*: Corresponding Author, Email: hrm_61@yahoo.com 